\title{
Past and recent changes in the North Atlantic oscillation
}

\author{
Article \\ Published Version
}

Pinto, J. G. and Raible, C. C. (2012) Past and recent changes in the North Atlantic oscillation. Wiley Interdisciplinary Reviews: Climate Change, 3 (1). pp. 79-90. ISSN 1757-7799 doi: https://doi.org/10.1002/wcc.150 Available at https://centaur.reading.ac.uk/32749/

It is advisable to refer to the publisher's version if you intend to cite from the work. See Guidance on citing.

Published version at: http://dx.doi.org/10.1002/wcc.150

To link to this article DOI: http://dx.doi.org/10.1002/wcc.150

Publisher: Wiley

All outputs in CentAUR are protected by Intellectual Property Rights law, including copyright law. Copyright and IPR is retained by the creators or other copyright holders. Terms and conditions for use of this material are defined in the End User Agreement.

\section{www.reading.ac.uk/centaur}

\section{CentAUR}

Central Archive at the University of Reading

Reading's research outputs online 


\section{Past and recent changes in the North Atlantic oscillation}

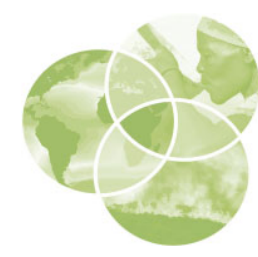

Joaquim G. Pinto ${ }^{1 *}$ and Christoph C. Raible ${ }^{2,3}$

The North Atlantic oscillation (NAO) is under current climate conditions the leading mode of atmospheric circulation variability over the North Atlantic region. While the pattern is present during the entire year, it is most important during winter, explaining a large part of the variability of the large-scale pressure field, being thus largely determinant for the weather conditions over the North Atlantic basin and over Western Europe. In this study, a review of recent literature on the basic understanding of the NAO, its variability on different time scales and driving physical mechanisms is presented. In particular, the observed $\mathrm{NAO}$ variations and long-term trends are put into a long term perspective by considering paleo-proxy evidence. A representative number of recently released NAO reconstructions are discussed. While the reconstructions agree reasonably well with observations during the instrumental overlapping period, there is a rather high uncertainty between the different reconstructions for the pre-instrumental period, which leads to partially incoherent results, that is, periods where the NAO reconstructions do not agree even in sign. Finally, we highlight the future need of a broader definition of the NAO, the assessment of the stability of the teleconnection centers over time, the analysis of the relations to other relevant variables like temperature and precipitation, as well as on the relevant processes involved. () 2011 John Wiley \& Sons, Ltd.

How to cite this article:

WIREs Clim Change 2012, 3:79-90. doi: 10.1002/wcc.150

\section{INTRODUCTION}

$\mathrm{T}_{\mathrm{i}}$ he atmospheric circulation of the North Atlantic is dominated by the North Atlantic oscillation (NAO) in winter. The pattern consists of two centers of action located over Iceland and the Azores with an equivalent barotropic structure explaining approximately $40 \%$ of the winter variability of the troposphere pressure fields. ${ }^{1,2}$ The time scales of the NAO range from days to centuries, but the dominant scales are interannual to decadal. The state of the $\mathrm{NAO}$ is characterized by an index definition, which is often also interpreted as an indicator for the strength of the westerlies over the Eastern North

\footnotetext{
*Correspondence to: jpinto@meteo.uni-koeln.de

${ }^{1}$ Institute for Geophysics and Meteorology, University of Cologne, Cologne, Germany

${ }^{2}$ Climate and Environmental Physics, Physics Institute, University of Bern, Bern, Switzerland

${ }^{3}$ Oeschger Center for Climate Change Research, University of Bern, Switzerland
}

Atlantic. ${ }^{1}$ Thus, changes in NAO phase are associated with characteristic changes of surface temperature, precipitation, and storm tracks, not only over the North Atlantic basin and Europe but also over parts of the Northern America, the Mediterranean basin and Eurasia. ${ }^{3}$ Nevertheless, these relationships to temperature and precipitation identified under 20th century climate conditions may be time dependent. ${ }^{4}$

Over the past 20-30 years, scientific research has focussed on decadal variability of the NAO, the associated physical mechanisms, particularly the coupling with the ocean and the stratosphere, as well as connection to external forcing (e.g., solar activity, volcanoes). Recently, the observed variations of the NAO have been extended back in time using paleo evidence from a variety of different proxy archives. ${ }^{5-17}$ Still, the existing NAO reconstructions show large uncertainties for the pre-instrumental period leaving room for partly contradicting interpretations and results. ${ }^{8-10,18,19}$ Thus, further improvement of the understanding of the NAO variability is important not only to estimate 
the range of possible fluctuations, but also to assess their predictability and possible shifts associated with increasing greenhouse gas concentrations. ${ }^{1,2}$

In this study, we present first an overview of the basic concept of the NAO. Second, recent changes of the NAO as well as evidences of potential underlying mechanisms are introduced. In a third step, paleo evidences of NAO changes in the last 1000 years, for example, periods of NAO phase locks or changes in the dominant frequencies, are presented, including a critical discussion of these results. Finally, conclusive remarks and a short outlook of open research questions related to the NAO follows.

\section{WHAT IS THE NAO?}

The first descriptions of phenomena associated with the NAO were given by Scandinavian sailors who realized that winter temperatures in Greenland and Scandinavia vary in opposite phase. ${ }^{1,20-22}$ The colonization of Greenland began in 985, and until 1300 ships frequently sailed between Scandinavia and Greenland, enabling a detailed understanding of weather, climate, and its remote links. ${ }^{23}$ First published work dates back to the mid-18th century ${ }^{24,25}$ focussing on the description of thermal and hydrological conditions in Greenland versus Scandinavia. In 1811, Gronau ${ }^{26}$ described the links between the weather conditions in Greenland and Germany. Later studies ${ }^{27}$ confirmed these relationships by analyzing early temperature time series. The concept of the NAO with two pressure centers of action appeared in the late 19th and early 20th century. ${ }^{28-30}$ Two factors were crucial for this development: (1) the availability of pressure data via the early measurement network over Europe and partly the North Atlantic and (2) the development of the correlation analysis. Nowadays, the NAO is described as equivalent barotropic teleconnection pattern or spatial oscillation in the troposphere over the North Atlantic European sector ${ }^{31}$ with strong connections to the regional weather and climate, particularly during winter. ${ }^{32}$ However, it should be mentioned that the NAO is the only atmospheric circulation pattern which can be identified for each month of the year. ${ }^{33}$

To further illustrate the NAO and its relationships to other variables like temperature and precipitation on interannual time scales, a schematic overview for the positive and the negative phase of the $\mathrm{NAO}$ is presented separately in Figure 1 (provided by $\mathrm{H}$. Wanner). ${ }^{1}$ This figure summarizes findings based on correlation and composite analysis for presentday climate conditions. A positive NAO phase is characterized by an intensified Azores High and deeper Iceland Low leading to a stronger meridional pressure gradient over North Atlantic, a more zonal flow regime and stronger westerlies, in particular of the central and eastern North Atlantic (Figure 1(a)). This typically leads to unsteady weather conditions over Western and Central Europe, characterized by a succession of low pressure centers embedded in the westerly flow. Additionally, this NAO phase is associated with warmer and wetter conditions over Northern Europe and dryer conditions over Southern Europe (Figure 1(a)). The imprint on the ocean of the NAO shows a tripole pattern in the sea surface temperatures (SSTs) with negative SST anomalies in the Greenland and Irminger Seas to Newfoundland and positive SST anomalies in the central North Atlantic and again negative SST anomalies further south at the west African coast (Figure 1(a)).

During a negative phase of the NAO, the Azores High is weaker and the Iceland Low is shallower. This atmospheric circulation pattern leads to a reduced meridional pressure gradient and weaker westerlies over the North Atlantic and Western Europe (Figure 1(b)). Over Southern Europe, the negative phase leads to unsteady weather conditions, typically wetter than normal, while over Northern Europe dryer and colder conditions are found, typically associated with a blocking (stationary high) situation extending from Ural/Eastern Europe to Western/Central Europe. Such a blocking high may remain in place for several weeks, leading to stable weather conditions over Central Europe. The SST anomalies during a negative phase of the NAO (Figure 1(b)) are opposite sign to the positive phase (Figure 1(a)).

Besides, the NAO is closely connected with the variability of the North Atlantic storm track-an area between Newfoundland, Iceland and Northern Europe with enhanced synoptic activity, or, in other words, with the frequent passage of synoptic disturbances (high and low pressure centers). During positive NAO phases, there is a constant passage of low pressure systems from the North Atlantic toward Northern Europe leading to an intensified, north eastward tilted storm track, roughly directed toward the Arctic at its exit. ${ }^{34-36}$ In contrast, negative NAO phases are characterized by more zonal oriented and typically shorter trajectories of low pressure systems. This leads to a weaker and southwardly displaced storm track, typically directed toward the Iberian Peninsula at its exit area. ${ }^{34-36}$ As described above, these shifts of the storm track are closely associated with wetter/dryer and warmer/colder conditions over different parts of Europe. For Western and Central Europe, most windstorms occur in conjunction with a slightly positive $\mathrm{NAO}$ phase $\mathrm{e}^{36,37}$ illustrating the importance of the NAO for socio-economic impacts. 

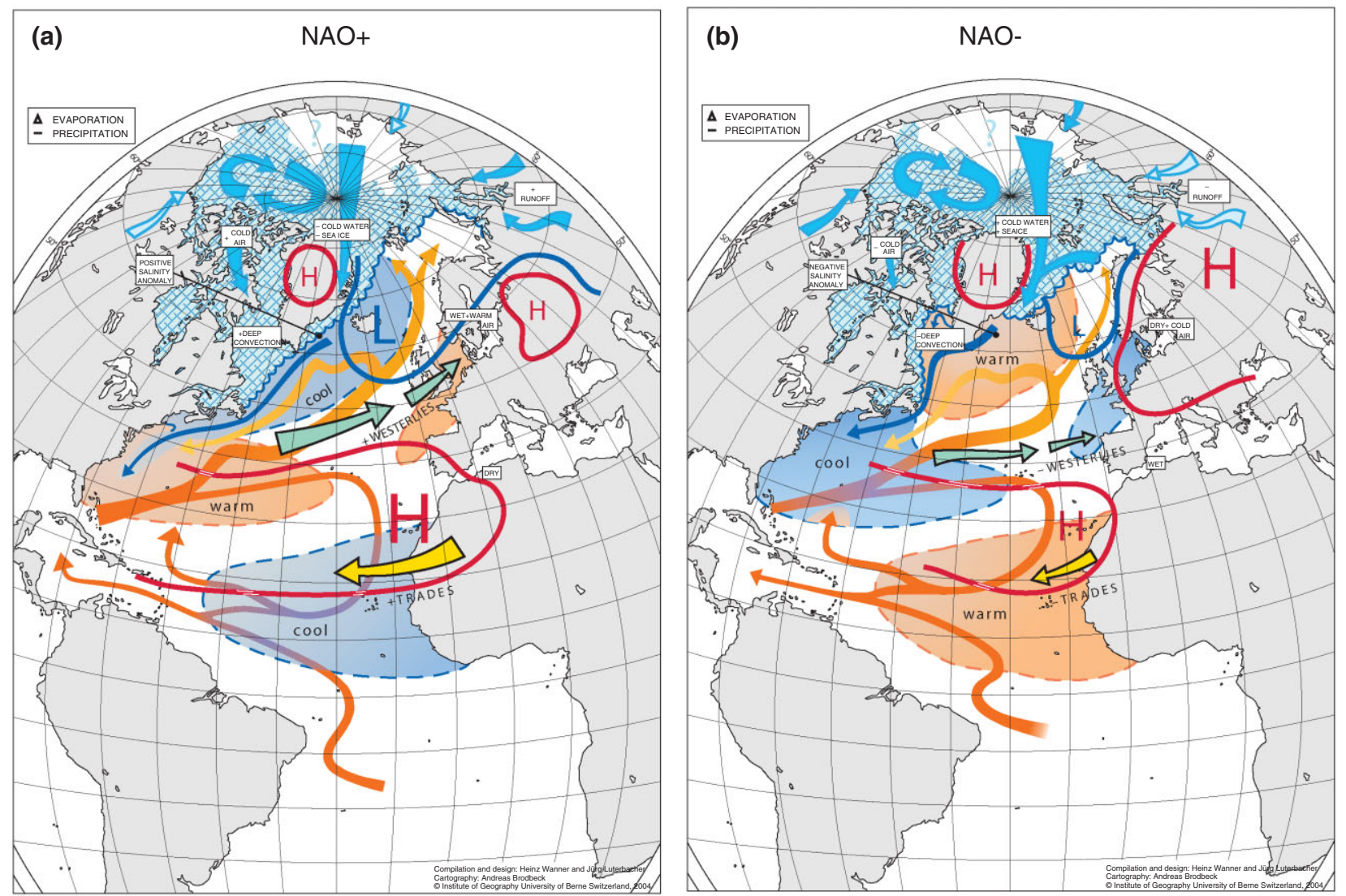

FIGURE 1 | A schematic overview of the two states of the NAO presented by Wanner et al. ${ }^{1}$ Shading indicates SSTs (bordered by dashed contours) and sea-ice extension; arrows show the flow systems in ocean, atmosphere and rivers; solid blue and red contours indicate sea level pressures; white rectangles describe either characteristic climate conditions or important processes: (a) The positive phase and (b) the negative phase of the NAO. Source: Wanner et al. ${ }^{1}$

\section{RECENT CHANGES OF THE NAO AND ASSOCIATED MECHANISMS}

Besides the spatial structure of the NAO and its associated impacts on other important climate variables and features, the variability of this teleconnection is investigated, particularly for decadal and centennial time scales to assess its potential of long term predictability. Still, the NAO also varies on shorter time scales, such as the daily scale. ${ }^{36,38}$ In particular, Pinto et al. ${ }^{36}$ have identified a close relationship between the occurrence of intense storms over the North Atlantic basin and strongly positive NAO index values. To assess the time behavior of the NAO the authors utilize an index approach, which can be quantified in a multitude of ways: (1) an index based on weather station data from Iceland and Azores/Lisbon/Gibraltar, 32,39,40 (2) a pattern-based definition, normally using principal component analysis to extract the leading mode of variability over the North Atlantic from mean sea level pressure (MLSP) data, ${ }^{33}$ and (3) correlation techniques. ${ }^{31,41}$ These definitions led to slightly different NAO indices, and also to different characteristic spatial patterns. However, the different NAO indices are strongly correlated $(r=0.71-0.97)$ with each other. ${ }^{42}$ While the NAO is typically a winter phenomena, its index may be determined for each month of the year. ${ }^{33}$ For example, Portis et al. ${ }^{41}$ define a mobile NAO index to characterize the seasonality of the locations of the centers of action. Their work ${ }^{41}$ provide evidence that the NAO centers move eastward in the summer months compared to its winter location, resembling earlier findings. ${ }^{43}$ Still, as the NAO is mostly expressed in the winter season, this review concentrates on the winter season.

The seminal study of Hurrell ${ }^{32}$ provided evidence that the NAO has shifted phase over the last 130 years (Figure 2): from a predominantly more negative phase before 1910, the NAO shifted first to a more positive phase in the 1920 s, followed by a negative trend enduring until the late 1960s. Afterwards, a strong positive trend is observed, which persists until the mid-1990s. In the past 15 years, a negative trend of the NAO indices is observed. This trend culminated in 


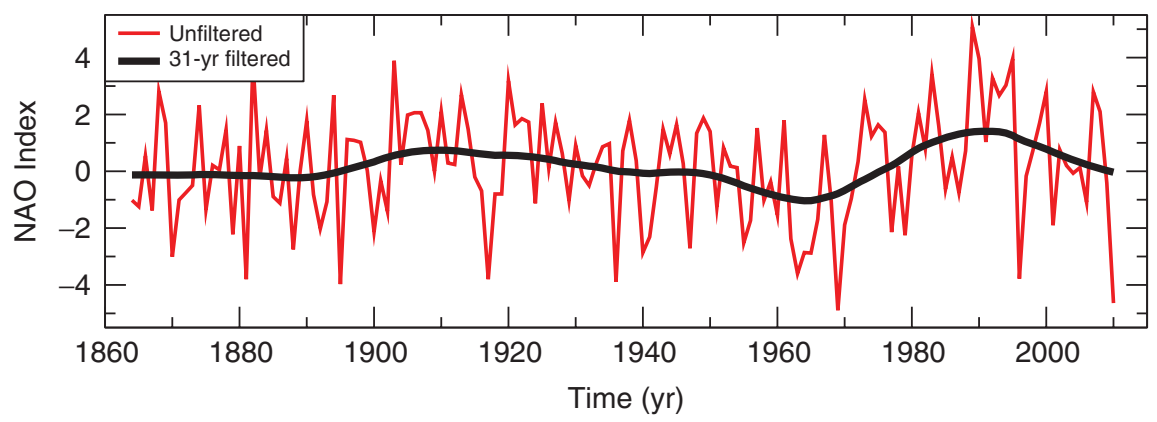

FIGURE 2 | Time series of the station-based NAO index from 1864 to 2009 for the season DJFM (updated data from the web page http://www.cgd.ucar.edu/cas/jhurrell/indices.html). ${ }^{32}$ In red the data represent unfiltered data from year to year; in black a 31-year filter is applied to illustrate the low-frequency behavior.

the consecutive winters of 2009/2010 and 2010/2011, which were among of the most negative winters in terms of the NAO during the past 150 years. ${ }^{44,45}$ While many possible factors for this recent trend have been discussed in the literature, including the tropical atmospheric circulation, snow cover extension, and the stratospheric vortex, ${ }^{46,47}$ results by Jung et al. ${ }^{44}$ support the hypothesis that dynamical atmospheric processes played a major role at least for the strongly negative NAO in the 2009/2010 winter.

Given that the storm activity is closely connected to the NAO, ${ }^{36,37}$ strong decadal variations have also been identified for winter storminess over the North Sea region during the last 130 years, with a peak at the beginning of the 20th century, a relative minimum in the early 1960s, followed by a peak in the early 1990s, and a reduction afterwards. ${ }^{48-50}$ Thus, the long term changes in storminess follow closely those of the NAO index ${ }^{32}$ for the last 130 years, even though they were derived from different instrumental data.

Clearly, the importance of the NAO for the winter circulation over the North Atlantic and Europe as well as its low-frequency variability (10 years and longer) motivated the assessment of possible underlying physical mechanisms, and have led to vital debates in the scientific community during the past 15 years. ${ }^{1,51}$ Still, the origin of the low-frequency variability is currently under debate: several authors suggested that external parameters, like volcanos, ${ }^{52,53}$ solar activity, ${ }^{53,54}$ or stratospheric-tropospheric coupling, ${ }^{55,56}$ are the major drivers of the lowfrequency variability, while other authors suggest internal variability of the atmosphere, that is, wave-wave interaction, is a leading factor. ${ }^{57-60}$ The coupling between the ocean and the atmosphere is apparently also of great importance for the decadal and longer time scales of NAO variability, as demonstrated both in observational and climate modeling studies. 1,61,62 Some studies consider SST anomalies over the underlying North Atlantic
Ocean as crucial, ${ }^{51}$ particularly feedback processes associated with the Atlantic meridional overturning circulation. ${ }^{63}$ Other studies provided evidence of links to tropical SSTs, either over the Indian Ocean ${ }^{64}$ or the Pacific Ocean. ${ }^{65,66}$ Recently, some authors analyzed the influence of upstream atmospheric variability, in particular the Pacific North American pattern, in steering the NAO phase. ${ }^{67}$ Many of the above mentioned studies use global climate model (GCM) simulations to evaluate the dynamical features of the NAO. However, GCMs have difficulties in reproducing both the (inter-annual) variability of the NAO and the NAO response in recent decades to increased greenhouse gas forcing. ${ }^{68}$ The author ${ }^{68}$ concludes that the latter may be model dependent on the regional scale, even though the general large-scale MSLP changes are coherent in most GCMs.

Particularly this strong trend to a positive phase of the NAO from the mid-1960s to mid-1990s raised questions on the role of climate change as a potential cause for this trend. Investigating reanalysis data and model simulations Hoerling and colleagues hypothesized that the trend is caused by a positive SST trend over the Indian Ocean which may be related to global warming. ${ }^{2,64}$ However, other authors ${ }^{69-71}$ concluded from their analysis based on observations and model simulations that this positive NAO trend is not significantly different in a statistical way from the internal atmosphere-ocean variability.

An important finding of studies focussing on the time behavior of the NAO was that the low-frequency variability of the NAO is not stable in time, that is, there are phases with enhanced and reduced decadal variations. ${ }^{5}$ Motivated by the results of Appenzeller et al. ${ }^{5}$ a modeling study ${ }^{72}$ showed that during phases with enhanced decadal variability a strong connection between the NAO and the underlying North Atlantic Ocean (the forth-mentioned tripole SST pattern) is found. ${ }^{62}$ In contrast, periods with low decadal 
variability exhibit a preferential link to the SSTs of the tropical Pacific. ${ }^{72}$ Periods with higher influence of Indian and Pacific SSTs to the NAO have also been suggested by Hoerling et al. ${ }^{64}$ Further, Pinto et al. ${ }^{67}$ discuss the coupling between the Pacific North American pattern and the NAO, also identifying phases with stronger or weaker coupling of the two modes, that is, phases of stronger/weaker influence from the North Pacific region. These studies suggest a way to combine and reconciliate several competing hypotheses discussed earlier in the literature.

\section{PALEO EVIDENCES OF NAO CHANGES}

The increasing amount of proxy data generated in the last two to three decades enabled reconstructions of the past climate over Europe. Among others, several reconstructions of the NAO back to 1049 $\mathrm{AD}$ have been performed in the last 15 years. ${ }^{5,6,73-80}$ These proxy reconstructions are either based on single proxy archives (e.g., ice cores ${ }^{5}$ ), on only pressuresensitive proxy data distributed over Europe, ${ }^{79,80}$ or on multi-proxies from different archives (e.g., tree rings, speleotherms, documentary) which are sensitive to temperature and/or precipitation. ${ }^{6,73}$ Such reconstructions are performed with different statistical methods, which estimate a statistical relationship between the proxy and climate data in the overlapping instrumental period (so-called calibration period). All methods have a common basic assumption that the relationship between the proxy and the climate data is stationary in time. Moreover, some reconstruction methods use regression techniques based on ordinary least squares, which are known to reduce variance. ${ }^{73}$

To illustrate the current state of knowledge, a selection of available NAO reconstructions is presented in Figure 3 focusing on the low-frequency part of variability. To highlight these low frequency variations, a 31-yearr time filter is applied to the different NAO reconstructions. Note that one reconstruction ${ }^{6}$ only represent such low-frequency variability due to the temporally coarse resolved proxy data used in this reconstruction. As some reconstructions under or overestimate the low-frequency variability due to statistical methods used, all filtered time series are normalized to enable an easier comparison. Moreover, most of the NAO reconstructions also provide an uncertainty range. Such uncertainty ranges are, however, omitted in Figure 3 for the sake of clarity. The uncertainty may steam from dating uncertainties, for example, for stalagmite record used in $^{6}$ has a dating uncertainty of $+/-20$ years, or the calibration error when applying the statistical method to the data. For example, if using a linear regression technique the calibration uncertainty could be estimated by the $95 \%$ confidence interval of the regression coefficient obtained during the calibration period. ${ }^{6}$ For some of the reconstructions the uncertainty increases further back in time. The reasons are manifold, encompassing among others the reduction of the number of proxies when going back in time, their quality, which could vary over time, their location and the individual connection of each proxy to the NAO. Still, the range of the different NAO reconstructions itself gives a hint of the uncertainty. In general, the reconstructions (Figure 3) agree reasonably well with observations ${ }^{32}$ during the instrumental overlapping period, which is used for calibration. An important aspect revealed in these NAO reconstructions is that the variability of the NAO during the 20th century, in particular the peak during the early nineties, is not necessarily unusual in terms of the variability of the NAO in the past six centuries, particularly before $1650 .{ }^{73,74}$

However, some of the reconstructions show considerable disagreement already in the period 1864-1900. These inconsistencies are partly because of the fact that some authors use different calibration periods for their reconstructions. ${ }^{19}$ In centuries prior to observations, during the time of the so-called Little Ice age, the low-frequency variability shows periods of better agreement (e.g., around 1620-1720) and periods of strong disagreement $(15 \mathrm{th}, 16 \mathrm{th}$, and 18 th to early 19th century). One plausible reason for the disagreement lies in the proxies used for the reconstruction. Some authors use growing-season-related proxies to reconstruct the winter NAO, which could at least have some impact on the quality of the reconstruction. Another plausible explanation is that the statistical relationships between some proxies and the NAO may be nonstationarity. ${ }^{19}$ Further, the number of proxies used may differ considerably between reconstructions. An example of the location of proxy records used to reconstruct the NAO index is shown in Figure 4. The blue correspond to the location of the precipitation sensitive proxies used in Trouet et al., ${ }^{6}$ and yellow to dark red the proxy locations used in Kuettel et al. ${ }^{79}$ The red boxes are $8^{\circ} \times 8^{\circ}$ grid boxes sampling wind speed and direction derived from ship log books. ${ }^{81}$

Besides reconstructing the $\mathrm{NAO}$ simulations of the past millennium performed with complex atmosphere-ocean general circulation models provide the ability to assess the NAO variations. ${ }^{53,82-85}$ Although there are several simulations and ensemble simulations with different models available a systematic model inter-comparison with respect to the NAO is still missing. So far, the focus was set to specific periods of the past, like the Maunder Minimum (1645-1715), a period of prolonged low solar activity. 
(a)

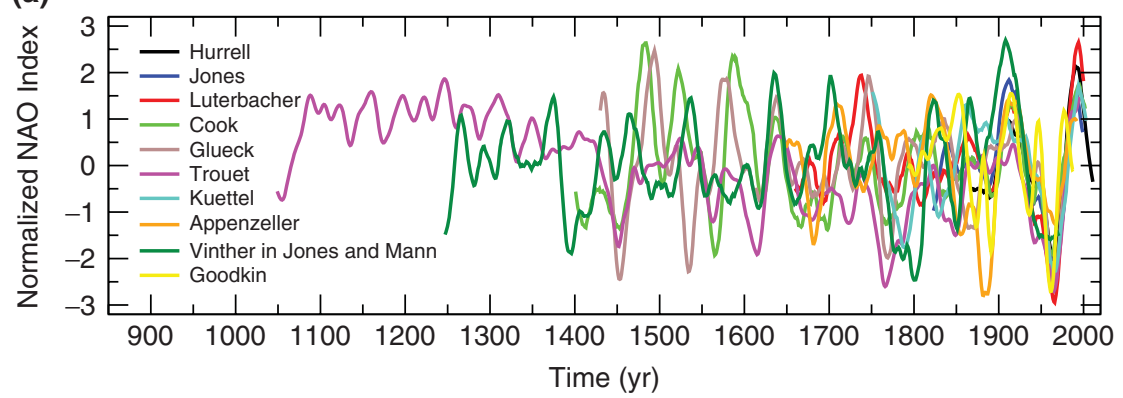

(b)

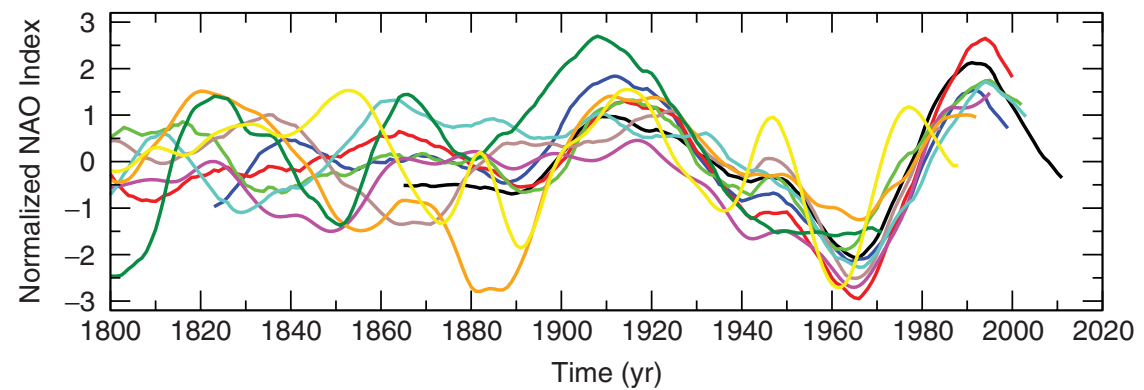

FIG URE 3 | (a) Low-frequency variability of different NAO reconstructions ${ }^{5,6,16,73-79}$ for the past millennium and of observations from 1864 to $2009^{32}$ (Figure 2). To focus on low-frequency variations a 31-year time filter is applied to the data except for the NAO reconstructions by Trouet and et al., ${ }^{6}$ which only reconstructed the low-frequency variations (also using a slightly different 31 -year time filter). Note that the indices of Trouet et al., ${ }^{6}$ Hurrell, ${ }^{32}$ Cook et al. ${ }^{74}$ represent the season DJFM, whereas the others are estimated for the season DJF. Because of the reconstructions methods the variance is underestimated. To make the indices comparable the low-frequency time series are normalized. The Kuettel index ${ }^{79}$ is based on selected grid points near Iceland and Lisbon of the sea level pressure fields provided and then the index is calculated similar to the method of Hurrel. ${ }^{32}$ (b) As (a) but only showing the period starting 1800.

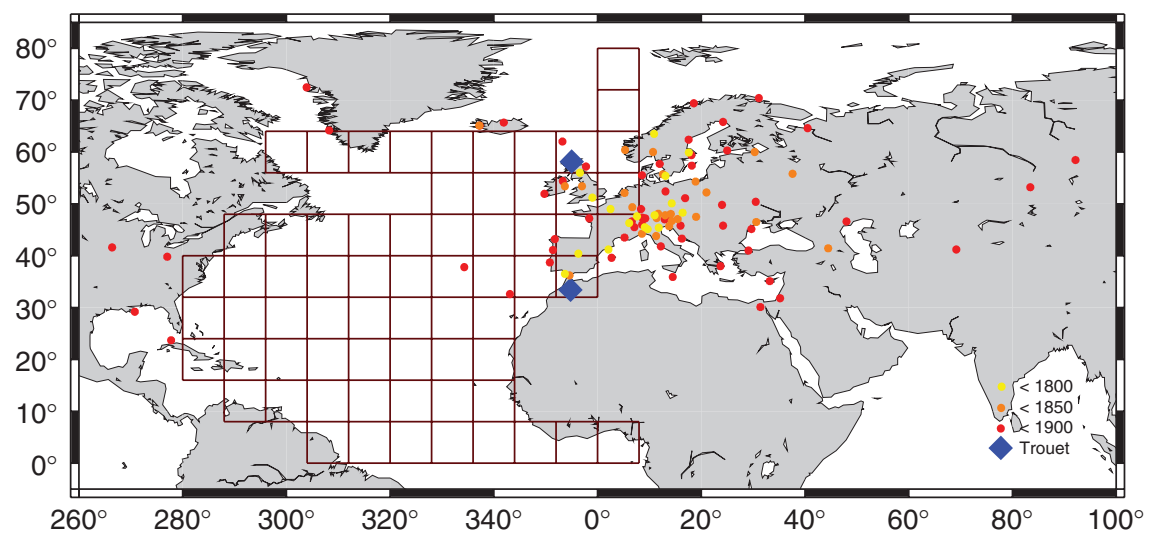

FIGURE 4 | An example of the location of proxy records used to reconstruct the NAO index: in blue the precipitation sensitive proxy locations used in Trouet et al., ${ }^{6}$ in yellow to dark red the proxy locations (only pressure sensitive) used in the MSLP reconstruction of Kuettel et al. ${ }^{79}$ Note that the proxy records of Trouet et al. ${ }^{6}$ span the period 1000-1995, whereas the proxy records of Kuettel span different periods; the red boxes are $8^{\circ} \times 8^{\circ}$ grid boxes sampling wind speed and direction derived from ship log books from 1662 to $1855,{ }^{81}$ where $99.6 \%$ span the period from 1750 to $1855 .{ }^{79}$

During this period Spangehl et al. ${ }^{53}$ found in a multimodel ensemble a predominantly negative phase of the NAO, confirming earlier modeling results. ${ }^{83,84}$ These authors $^{53}$ showed that the signal of external forcing like the solar forcing is only visible in periods of high deviations of the external forcing, like the Maunder Minimum. Therefore, the negative phase of the NAO during the Maunder Minimum is interpreted as a robust forcing signal. Nevertheless, a recent modeling study $^{86}$ hypothesized that the response of the NAO to solar forcing could be lagged by up to 50 years because of a northward shift of the convection in the tropical Pacific accompanied by a wave train reaching the North Atlantic. Comparing these modeling 
results with the reconstructions presented in Figure 3 we find that although the uncertainty is high due to the strong discrepancies among the NAO reconstructions, the reconstructions agree during the Maunder Minimum and show a negative phase of the NAO. Another important and robust forcing signal is the link of tropical volcanic eruptions to the NAO. ${ }^{52,87}$ The postulated positive phase of the NAO 1-2 years after an eruption is also identified in pressure reconstructions. ${ }^{52,88}$ Another way to use model simulations is to test reconstruction in the model world. ${ }^{89}$ These authors showed that temperature sensitive proxies are less reliable in reconstructing the NAO. Additionally, they exhibit that the reconstruction sensitively relies on the selected regions, which give an additional hint on the origin of the uncertainty of NAO reconstructions.

Concerning the reconstructions, a striking feature is the prolonged positive NAO phase during the period 1000-1450 $\mathrm{AD}^{6}$ (Figure 3). This reconstruction, ${ }^{6}$ based on precipitation sensitive proxies (Figure 3), still has to be confirmed by other studies, but in fact it has stimulated a series of papers in its wake. The discussion deals with the fact that the proxy evidence on storminess, which could reflect NAO variability (this is the case during the 20th century, see above, but not necessarily the case in earlier periods), contradicts a shift from a positive phase of NAO during the period 1000-1450 to the Little Ice Age (around 1620-1720). ${ }^{90,91}$ A newly available study ${ }^{18}$ provides some first hints on how to reconcile the differences between the two proxies. These authors employ modeling results, ${ }^{92}$ which suggest that during negative phases of the NAO the mid latitude cyclones could be intensified, but decreased in number. Thus, Trouet et al. ${ }^{18}$ hypothesize that storm sensitive proxies of the North Atlantic might reflect an increase in storm intensity rather than storm frequency. Still this suggestion needs to be supported by additional multimodel ensemble simulations spanning the entire last millennium. Recently available simulations of the past millennium show that although the link between $\mathrm{NAO}$ and precipitation, which is the baseline of the Trouet reconstruction, ${ }^{18}$ is reasonably well simulated, the temporal behavior of the NAO is to a great extent dominated by internal variability ${ }^{82}$ with the exception of periods with high deviations of the external forcing (Maunder and Dalton Minimum, strong volcanic eruptions, see discussion above).

Besides the low-frequency variability, the spatial-temporal evolution has been another focus of research. The position of the centers of action shows a clear seasonality, that is, a northward shift in the summer season with respect to the winter. ${ }^{41}$ Further, several studies have discussed an eastward shift of the NAO centers of action for 1978-1997 compared to previous decades. ${ }^{93}$ Moreover, the location of the pressure centers of the NAO are shifted northeasternwards in simulations with increasing greenhouse gas of the 21st century. ${ }^{94}$ Extending the spatial-temporal evolution further back in time teleconnection patterns based on the teleconnectivity ${ }^{31}$ of the reconstructed $500-\mathrm{hPa}$ geopotential height fields ${ }^{88}$ are estimated in a running window of 30 -years from 1500 to $1999 .{ }^{85}$ These authors ${ }^{85}$ define so-called teleconnection axes connecting the two anticorrelated centers of action. To illustrate this, the axes for all 30-year windows of the period 1500-1999 are shown in Figure 5. Note that because of the rather coarse resolution of the reconstructions some axes are plotted on top of each other. Two typical orientations are found: a north to south orientation, which corresponds to the dominant mode under current climate conditions, and a northwest to southeast orientation, unknown in recent decades. Even though the reconstructed area does not span the entire North Atlantic and is therefore not perfect to deduce the NAO, the two typical orientations are also found in model simulations using an expanded area. ${ }^{85}$ Regarding the time evolution of the orientation of the NAO poles in the reconstructions, no clear link could be identified to external forcing. Therefore, these variations may be interpreted as internal variability.

The change of the location of the centers of action has strong implications: the atmospheric

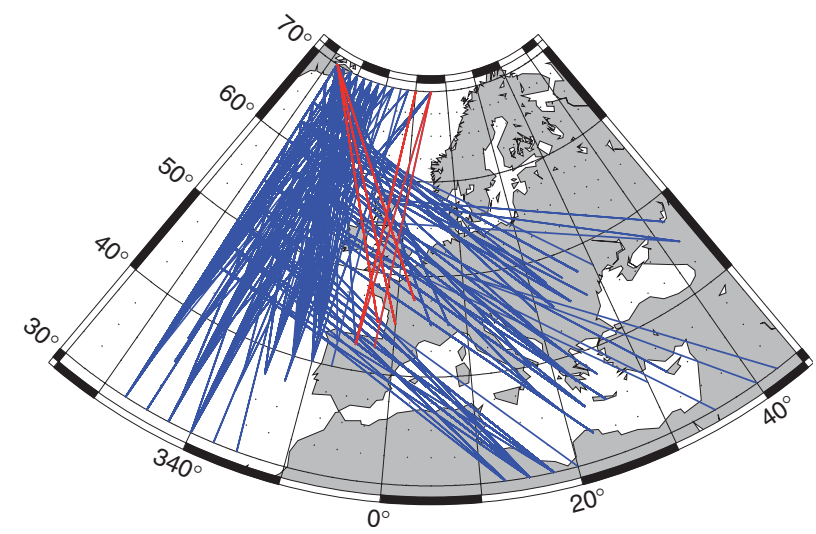

FIG URE 5 | Teleconnection axes deduced for a 30-year running window from teleconnectivity maps in winter (DJF). ${ }^{85}$ The teleconnectivity is based on $500 \mathrm{hPa}$ geopotential height ${ }^{88}$ (for the region $30^{\circ} \mathrm{W}-40^{\circ} \mathrm{E}$ and $30^{\circ} \mathrm{N}-70^{\circ} \mathrm{N}$ ) from 1500 to 1999 . All axes are projected in one plane, so some axes are plotted on top of each other. The axes of the last 50 years, which is the calibration period of this specific reconstruction (using NCEP/NCAR reanalysis data) are shown in red. Note that the axes connect the centers of action within a particular teleconnection pattern, that is, for the classical NAO, the Iceland Low and the Azores High. Additional to the axis the black dots show the grid points of the reconstruction. 
circulation is dominated by a meridional flow toward Europe (either southwesterly or northwesterly) during phases with northwest to southeast oriented teleconnection pattern. Such a flow pattern is in contrast to the present climate conditions, which feature a north to south orientation, that is, a more zonal flow (for a positive index using the identified centers of actions) or a more meridional flow (an anomalous eastwards flow in the case of a negative index when using the identified centers of actions to define it). Thus, a different location of the NAO centers of action can be expected to have had a strong impact on the European climate. Such changes over time have also been identified by Osborn et al., ${ }^{4}$ who provided evidence that the relationships between the NAO, temperature and precipitation may not be stable under recent climate conditions by analyzing a 1400 year control simulation with the HadCM2 GCM.

\section{CONCLUSION}

In this study, we have presented a review of the recent and past changes of the NAO focusing on its dominant low frequency variability, that is, time scales of decades to centuries. Several studies provide evidence that low frequency variability may not be stationary in time. The proposed hypotheses regarding the underlying physical mechanisms include not only the tropical atmospheric circulation, the intensity of stratospheric polar vortex, external forcing, like solar insolation, snow cover extension, sea surface temperature, and sea ice anomalies, but also of internal dynamical atmospheric processes. ${ }^{1,2,44-67}$ Still, it is an open question which mechanisms have contributed to which long-term shift of the NAO index, for example, the low NAO values during the Maunder Minimum (1645-1715) or the strong positive trend from the 1960 s to the 1990s. The large variety of hypotheses could explain why the identification of the driving mechanism of the low-frequency NAO variations is still not settled.

In recent years, several attempts have been performed to extend the NAO time series back to 1500 or earlier. In this study, all available NAO reconstructions are presented spanning a rather wide range during pre-instrumental period and thus illustrate the high uncertainty of past NAO evolution.
During some periods, there is good agreement between the reconstructions (e.g., 1620-1720) while for others there is strong disagreement (e.g., 18th to early 19th century). A common problem to methods is the assumption of a stationary relationship between the proxies and the NAO, which may not be necessarily true at least for some of the proxy data. Another problem is the reduction of variance seen in several of the reconstructions, which is associated with the use of regression techniques based on ordinary least square estimation. Additional to the temporal changes of the NAO index, possible changes in the location of the NAO poles over time were discussed. In this context, evidence was given that the influence of the $\mathrm{NAO}$ on the European climate is different for periods with a different orientation of the NAO centers. This is particularly important for the proxy community as structural changes of the NAO could either destroy the statistical relationship between proxy record and the NAO or changes recorded in the proxy could be generated by a different atmospheric circulation pattern.

On the basis the review above, some pertinent but still pending questions arise for future research. Clearly, there is a need to re-evaluate reconstruction techniques to avoid the problem of diminishing variance when going back in time. Further, these reconstruction techniques should be tested in the model world ${ }^{89}$ to analyze the coherence between the different proxy data and to separate external forcing from natural climate variability. ${ }^{95}$ In particular, a comprehensive model comparison of all available simulations of the past millennium including the behavior of the $\mathrm{NAO}$ will be very pertinent in the near future. Such studies will help to better understand past NAO variability, evaluate its uncertainties, and provide hints to the underlying dominant processes and to enhance predictability of the $\mathrm{NAO}$ on decadal time scales. Finally, the concept of the NAO should become more flexible, considering other different viewpoints of the $\mathrm{NAO}$, in particularly its description as Rossby wave breaking events of cyclonic/anticyclonic characteristics and its close link to blocking. ${ }^{60,96-98}$ Such a new concept should enable the consideration of both shifts in pattern and magnitude over time.

\section{ACKNOWLEDGMENTS}

The authors would like to thank H. Wanner for providing Figure 1 and V. Trouet for making the data available. C.C.R. is supported by the National Centre for Competence in Research (NCCR) on Climate funded by the Swiss National Science Foundation (SNF) as well as the SNF Sinergia Project FUPSOL. 


\section{REFERENCES}

1. Wanner H, Bronnimann S, Casty C, Gyalistras D, Luterbacher J, Schmutz C, Stephenson DB, Xoplaki E. North Atlantic oscillation. Concepts and studies. Surv Geophys 2001, 22:321-382.

2. Hurrell JW, Kushnir Y, Visbeck M, Ottersen G (eds.), An Overview of the North Atlantic Oscillation. The North Atlantic Oscillation, Geophysical Monograph Series, Vol. 134. Washington, DC: American Geophysical Union; 2003, 279.

3. Dickson RR, Osborn TJ, Hurrell JW, Meincke J, Blindheim J, Adlandsvik B, Vinje T, Alekseev G, Maslowski W. The Arctic ocean response to the North Atlantic oscillation. J Clim 2000, 13:2671-2696.

4. Osborn TJ, Briffa KR, Tett SFB, Jones PD, Trigo RM. Evaluation of the North Atlantic oscillation as simulated by a coupled climate model. Clim Dyn 1999, 15:685-702.

5. Appenzeller C, Stocker TF, Anklin M. North Atlantic oscillation dynamics recorded in Greenland ice cores. Science 1998, 282:446-449.

6. Trouet V, Esper J, Graham NE, Baker A, Scourse JD, Frank DC. Persistent positive north atlantic oscillation mode dominated the medieval climate anomaly. Science 2009, 324:78-80.

7. Barlow LK, White JWC, Barry RG, Rogers JC, Grootes PM. The North Atlantic Oscillation signature in deuterium and deuterium excess signals in the Greenland Ice Sheet Project 2 ice core, 1840-1970. Geophys Res Lett 1993, 20:2901-2904. doi:10.1029/93GL03305.

8. Cook ER, D’Arrigo RD, Briffa KR. A reconstruction of the North Atlantic oscillation using tree-ring chronologies from North America and Europe. Holocene 1998, 8:9-17.

9. Luterbacher J, Schmutz C, Gyalistras D, Xoplaki E, Wanner H. Reconstruction of monthly NAO and EU indices back to AD 1675. Geophys Res Lett 1999, 26:2745-2748. doi:10.1029/1999GL900576.

10. Timm O, Ruprecht E, Kleppek S. Scale-dependent reconstruction of the NAO index. J Clim 2004, 17:2157-2169.

11. Cullen HM, D’Arrigo RD, Cook ER, Mann ME. Multiproxy reconstructions of the North Atlantic oscillation. Paleoceanography 2001, 16:27-39.

12. Darrigo RD, Cook ER, Jacoby GC, Briffa KR. NAO and sea surface temperature signatures in tree-ring records from the North Atlantic sector. Quat Sci Rev 1993, 12:431-440.

13. Jones PD, Osborn TJ, Briffa KR. Pressure-based measurements of the North Atlantic Oscillation (NAO): a comparison and an assessment of changes in the strength of the NAO and in its influence on surface climate parameters. In: Hurrell JW, Kushnir Y, Ottersen G, Visbeck M, eds. North Atlantic Oscillation: Climatic Significance and Environmental Impact,
Geophysical Monograph. Washington: American Geophysical Union; 2003, 51-62. doi:10.1029/134GM03.

14. Mann ME. Large-scale climate variability and connections with the Middle East in past centuries. Clim Chan 2002, 55:287-314.

15. Rodrigo FS, Pozo-Vazquez D, Esteban-Parra MJ, Castro-Diez Y. A reconstruction of the winter North Atlantic oscillation index back to AD 1501 using, documentary data in southern Spain. J Geophys Res 2001, 106:14805-14818. doi:10.1029/2000JD900728.

16. Vinther BM, Johnsen SJ, Andersen KK, Clausen HB, Hansen HW. NAO signal recorded in the stable isotopes of Greenland ice cores. Geophys Res Lett 2003, 30:1387. doi:10.1029/2002GL016193.

17. White JWC, Barlow LK, Fisher D, Grootes P, Jouzel J, Johnsen SJ, Stuiver M, Clausen H. The climate signal in the stable isotopes of snow from Summit, Greenland: results of comparisons with modern climate observations. J Geophys Res 1997, 26:425-439. doi:10.1029/97JC00162.

18. Trouet V, Scourse JD, Raible CC. North Atlantic storminess and Atlantic Meridional Overturning Circulation during the last millennium: reconciling contradictory proxy records of NAO variability. Global Planet Change 2011. doi:10.1016/j.gloplacha.2011.10.003.

19. Schmutz C, Luterbacher J, Gyalistras D, Xoplaki E, Wanner H. Can we trust proxy-based NAO index reconstructions? Geophys Res Lett 2000, 27:1135-1138. doi:10.1029/1999GL011045.

20. Stephenson DB, Wanner H, Brönnimann S, Luterbacher J. The North Atlantic oscillation. Climatic significance and environmental impact. Geophys Monograph Ser 2003, 134:37-50.

21. Luterbacher J, Brönnimann S, Wanner H. The history of scientific Research on the North Atlantic Oscillation/Historische Entwicklung der Nordatlantischen Oszillations-Erforschung. Promet (Meteorologische Fortbildung), special issue on the North Atlantic Oscillation (NAO) 2008, 3/4:79-88.

22. Hense A, Glowienka-Hense R. Comments on: on the weather history of North Greenland, west coast by Julius Hann. Meteorol Z 2010, 19:207-211.

23. Haine T. What did the Viking discoverers of America know of the North Atlantic Environment? Weather 2008, 63:60-65.

24. Egede H. History of Greenland - A Description of Greenland: Shewing the Natural History, Situation, Boundaries, and Face of the Country; the Nature of the Soil; the Rise and Progress of the Old Norwegian Colonies; the Ancient and Modern Inhabitants; their Genius and Way of Life, and Produce of the Soil; their Plants, Beasts, Fishes, 6oc.' (translated from the Danish). 1745. Picadilly, London: Pickering Bookseller; 220. 
25. Crantz D. The History of Greenland; Including an Account of the Mission Carried on by the United Brethren in that Country. London: Longman, Hurst, Rees, Orme and Brown; 1765, 1820, xi, 359 pp; 2 volumes, vi, 323

26. Gronau KL. Das Klima der Polarländer. In: Flörke HF, ed. Repertorium des Neuesten und Wissenwürdigsten aus der gesamten Naturkunde. Berlin: 1811.

27. Dove HW. Über die geographische Verbreitung gleichartiger Witterungserscheinungen. Erste Abhandlung: Über die nicht periodischen Änderungen der Temperaturvertheilung auf der Oberfläche der Erde. Abh. Königl. Akad. Wiss. Berlin, 1839, 287-415.

28. Teisserenc de Bort. Etude sur l'hiver de 1879-80 et recherches sur l'influence de la position des grands centres d'action de l'atmosphère dans les hivers anormaux. Ann de la Soc Météor de France 1883, 31:70-79.

29. Defant A. Die Schwankungen der atmosphärischen Zirkulation über dem Nordatlantischen Ozean im 25-jährigen Zeitraum 1881-1905. Geogr Ann 1924, $6: 13-41$.

30. Walker GT. Correlation in seasonal variation of weather. IX Mem Ind Met Dept 1924, 25:275-332.

31. Wallace JM, Gutzler DS. Teleconnections in the geopotential height field during the Northern Hemisphere winter. Mon Weather Rev 1981, 109:784-812.

32. Hurrell JW. Decadal trends in the North Atlantic Oscillation and relationships to regional temperature and precipitation. Science 1995, 269:676-679.

33. Barnston AG, Livezey RE. Classification, seasonality and persistence of low-frequency atmospheric circulation patterns. Mon Weather Rev 1987, 115:1083-1126.

34. Sickmöller M, Blender RK, Fraedrich K. Observed winter cyclone tracks in the northern hemisphere in reanalysed ECMWF data. Q J R Meteorol Soc 2000, 126:591-620.

35. Raible CC. On the relation between extremes of midlatitude cyclones and the atmospheric circulation using ERA40. Geophys Res Lett 2007, 34:L07703. doi:10.1029/2006GL029084.

36. Pinto JG, Zacharias S, Fink AH, Leckebusch GC, Ulbrich U. Factors contributing to the development of extreme North Atlantic cyclones and their relationship with the NAO. Clim Dyn 2009, 32:711-737.

37. Donat MG, Leckebusch GC, Pinto JG, Ulbrich U. Examination of Wind Storms over Central Europe with respect to Circulation Weather Types and NAO phases. Int J Climatol 2010, 30:1289-1300.

38. Blessing S, Fraedrich K, Junge M, Kunz T, Linkheit F. Daily North-Atlantic Oscillation (NAO) index: statistics and its stratospheric polar vortex dependence. Meteorol Z 2005, 14:763-769.

39. Jones PD, Jónsson T, Wheeler D. Extension to the North Atlantic Oscillation using early instrumental pressure observations from Gibraltar and South-West Iceland Int J Climatol 1997, 17:1433-1450.

40. Vinther BM, Andersen KK, Hansen AW, Schmith T, Jones PD. Improving the Gibraltar/Reyjavik NAO Index. Geophys Res Lett 2003, 30:2222. doi:10. 1029/2003GL018220.

41. Portis DH, Walsh JE, Hamly ME, Lamb PJ. Seasonality of the North Atlantic Oscillation. J Clim 2001, 13:2069-2078.

42. Leckebusch GC, Kapala A, Mächel H, Pinto JG, Reyers M. Indices of the North Atlantic and Artic Oscillations/Indices der Nordatlantischen und Arktischen Oszillation. Promet (Meteorologische Fortbildung), special issue on the North Atlantic Oscillation (NAO) 2008, 3/4:95-100.

43. Wanner H, Rickli R, Salvisberg E, Schmutz C, Schüepp M. Global climate change and variability and its influence on Alpine climate-concepts and observations. Theor Appl Climatol 1997, 58:221-243.

44. Jung T, Vitart F, Ferranti L, Morcrette J-J. Origin and predictability of the extreme negative NAO winter of 2009/10. Geophys Res Lett 2011, 38:L07701. doi:10.1029/2011GL046786.

45. Cattiaux J, Vautard R, Cassou C, Yiou P, MassonDelmotte V, Codron F. Winter 2010 in Europe: a cold extreme in a warming climate. Geophys Res Lett 2010, 37:L20704. doi:10.1029/2010GL044613.

46. Cohen J, Barlow M. The NAO, the AO, and global warming: how closely related? I Clim 2005, 18:4498-4513.

47. Overland JE, Wang M. The Arctic climate paradox: the recent decrease of the Arctic Oscillation. Geophys Res Lett 2005, 32:L06701. doi:10.1029/2004GL021752.

48. Group WASA. Changing waves and storms in the Northeast Atlantic? Bull Am Meteor Soc 1998, 79:741-760.

49. Alexandersson H, Tuomenvirta H, Schmith T, Iden K. Trends of storms in NW Europe derived from an updated pressure data set. Clim Res 2000, 14:71-73.

50. Wang XL, Zwiers FW, Swail VR, Feng Y. Trends and variability of storminess in the Northeast Atlantic Region, 1874-2007. Clim Dyn 2009, 33:1179-1195.

51. Marshall J, Kushnir Y, Battisti D, Chang P, Czaja A, Dickson R, Hurrell J, McCartney M, Saravanan R, Visbeck M. North Atlantic climate variability: phenomena, impacts and mechanisms. Int J Climatol 2001, 21:1863-1898.

52. Fischer EM, Luterbacher J, Zorita E, Tett SFB, Casty C, Wanner H. European climate response to tropical volcanic eruptions over the last half millennium. Geophys Res Lett 2007, 34:L05707. doi:10.1029/2006GL027992.

53. Spangehl T, Cubasch U, Raible CC, Schimanke S, Körper J, Hofer D. Transient climate simulations from the Maunder Minimum to present day: role of 
the stratosphere. J Geophys Res 2010, 115:D00I10. doi:10.1029/2009JD012358.

54. Shindell DT, Schmidt GA, Mann ME, Rind D, Waple A. Solar forcing of regional climate change during the Maunder Minimum. Science 2001, 294:2149-2152.

55. Perlwitz J, Graf H-F, Voss R. The leading variability mode of the coupled troposphere-stratosphere winter circulation in different climate regimes. J Geophys Res 2000, 105:6915-6926.

56. Scaife AA, Knight JR, Vallis G, Folland CK. A stratospheric influence on the winter NAO and north Atlantic surface climate. Geophys Res Lett 2005, 32:L18715.

57. James IN, James PM. Ultra-low frequency variability in a simple atmospheric circulation model. Nature 1989, 342:53-55.

58. Franzke C, Fraedrich K, Lunkheit F. Low frequency variability in a simplified atmospheric global circulation model: storm track induced 'spatial resonance. Quart J Roy Meteorol Soc 2000, 126:2691-2708.

59. Feldstein SB. The timescale, power spectra, and climate noise properties of teleconnection patterns. J Clim 2000, 13:4430-4440.

60. Woollings TJ, Hoskins BJ, Blackburn M, Berrisford P. A New Rossby Wave-breaking Interpretation of the North Atlantic oscillation. J Atmos Sci 2008, 65:609-626.

61. Lau NC. Interactions between global SST anomalies and the midlatitude atmospheric circulation. Bull Am Meteorol Soc 1997, 78:21-33.

62. Bjerknes J. Atlantic air-sea interaction. Adv Geophys 1964, 10:1-82.

63. Timmermann A, Latif M, Voss R, Grötzner A. North Atlantic interdecadal variability: a coupled air-sea mode. J Clim 1998, 11:1906-1931.

64. Hoerling MP, Hurrell JW, Xu T. Tropical origins for recent North Atlantic climate change. Science 2001, 292:90-92.

65. Trenberth KE, Branstator GW, Karoly D, Kumar A, Lau NC, Ropelewski C. Progress during TOGA in understanding and modeling global teleconnections associated with tropical sea surface temperatures. J Geophys Res 1998, 103:14291-14324.

66. Müller WA, Frankignoul C, Chouaib N. Observed decadal tropical Pacific-North Atlantic teleconnections. Geophys Res Lett 2008, 35:L24810. doi:10.1029/2008GL035901.

67. Pinto JG, Reyers M, Ulbrich U. The variable link between PNA and NAO in observations and in multi-century CGCM simulations. Clim Dyn 2011, $36: 337-354$.

68. Osborn TJ. Simulating the winter North Atlantic Oscillation: the roles of internal variability and greenhouse gas forcing. Clim Dyn 2004, 22:605-623.
69. Wunsch C. The interpretation of short climate records, with comments on the North Atlantic and Southern Oscillations. Bull Amer Meteor Soc 1999, 80:245-255.

70. Schneider EK, Bengtsson L, Hu Z-Z. Forcing of Northern Hemisphere climate trends. J Atmos Sci 2003, 60:1504-1521.

71. Raible CC, Stocker TF, Yoshimori M, Renold M, Beyerle U, Casty C, Luterbacher J. Northern Hemispheric trends of pressure indices and atmospheric circulation patterns in observations, reconstructions, and coupled GCM simulations. J Clim 2005, 18:3968-3982.

72. Raible CC, Luksch U, Fraedrich K, Voss R. North Atlantic decadal regimes in a coupled GCM simulation. Clim Dyn 2001, 18:321-330.

73. Luterbacher J, Xoplaki E, Dietrich D, Jones PD, Davies TD, Portis D, Gonzalez-Rouco JF, von Storch H, Gyalistras D, Casty C, et al. Extending North Atlantic Oscillation Reconstructions Back to 1500. Atmos Sci Lett 2002, 2:114-124.

74. Cook ER, D’Arrigo RD, Mann ME. A well verified, multiproxy reconstruction of the winter North Atlantic Oscillation index since A.D. 1400. J Clim 2002, 15:1754-1764.

75. Glueck MF, Stockton CW. Reconstruction of the North Atlantic oscillation. Int J Climatol 2001, 21:1453-1465

76. Goodkin NF, Hughen KA, Doney SC, Curry WB. Increased multidecadal variability of the North Atlantic Oscillation since 1781. Nature Geosci 2008, 1:844-848.

77. Jones PD, Jonsson T, Wheeler D. Extensions to the North Atlantic oscillation using early instrumental pressure observations from Gibraltar and southwest Iceland. Int J Climatol 1997, 17:1433-1450.

78. Jones PD, Mann ME. Climate over the past millennia. Rev Geophys 2004, 42:RG2002. doi:10.1029/ 2003RG000143

79. Küttel M, Xoplaki E, Gallego D, Luterbacher J, GarciaHerrera R, Allan R, Barriendos M, Jones PD, Wheeler $\mathrm{D}$, Wanner H. The importance of ship log data: reconstructing North Atlantic, European and Mediterranean sea level pressure fields back to 1750. Clim Dyn 2010, 34:115-1128.

80. Casty C, Raible CC, Stocker TF, Wanner H, Luterbacher J. A European pattern climatology 1766-2000. Clim Dyn 2007, 29:791-805.

81. Wheeler D, Garcia-Herrera R, Wilkinson CW, Ward C. Atmospheric circulation and storminess derived from Royal Navy logbooks: 1685 to 1750 . Clim Change 2010, 101:257-280.

82. Gomez-Navarro JJ, Montavez JP, Jerez S, JimenezGuerrero P, Lorente-Plazas R, Gonzalez-Rouco JF, Zorita E. A regional climate simulation over the Iberian Peninsula for the last millennium. Clim Past 2011, 7:451-472. 
83. Stendel M, Mogensen IA, Christensen JH. Influence of various forcings on global climate in historical times using a coupled atmosphere-ocean general circulation model. Clim Dyn 2006, 26:1-15.

84. Zorita E, von Storch H, González-Rouco F, Cubasch U, Luterbacher J, Legutke S, Fischer-Bruns I, Schlese U. Climate evolution in the last five centuries simulated by an atmosphere-ocean model: Global tempertures, the North Atlantic Oscillation and the Late Maunder Minimum. Meteorol Z 2004, 13:271-289.

85. Raible CC, Casty C, Luterbacher J, Pauling A, Esper J, Frank DC, Buentgens U, Roesch AC, Wild M, Tschuck P, et al. Climate variability-observations, reconstructions and model simulations. Clim Change 2006, 79:9-29.

86. Swingedouw D, Terray L, Cassou C, Voldoire A, SalasMélia D, Servonnat J. Natural forcing of climate during the last millennium: fingerprint of solar variability. Clim Dyn 2011, 36:1349-1364.

87. Robock A. Volcanic eruptions and climate. Rev Geophys 2000, 38:191-219.

88. Luterbacher J, Xoplaki E, Dietrich D, Rickli R, Jacobeit J, Beck C, Gylistras D, Schmutz C, Wanner H. Reconstruction of sea-level pressure fields over the eastern North Atlantic and Europe back to 1500. Clim Dyn 2002, 18:545-561.

89. Zorita E, González-Rouco F. Are temperature-sensitive proxies adequate for North Atlantic Oscillation reconstructions? Geophys Res Lett 2002, 29:14. doi:10.1029/2002GL015404.

90. Meeker LD, Mayewski PA. A 1400-year highresolution record of atmospheric circulation over the North Atlantic and Asia. Holocene 2002, 12:257-266.
91. Dawson AG, Hickey K, Mayewski PA, Nesje A. Greenland (GISP2) ice core and historical indicators of complex North Atlantic climate changes during the fourteenth century. Holocene 2007, 17:427-434.

92. Raible CC, Yoshimori M, Stocker TF, Casty C. Extreme midlatitude cyclones and their implications to precipitation and wind speed extremes in simulations of the Maunder Minimum versus present day conditions. Clim Dyn 2007, 28:409-423.

93. Jung T, Hilmer M, Ruprecht E, Kleppek S, Gulev SK, Zolina O. Characteristics of the Recent Eastward Shift of Interannual NAO variability. J Clim 2003, $16: 3371-3382$.

94. Ulbrich U, Christoph M. A shift of the NAO and increasing storm track activity over Europe due to anthropogenic greenhouse gas forcing. Clim Dyn 1999, 15:551-559.

95. Von Storch H, Zorita E, Jones JM, Dimitriev Y, González-Rouco F. Tett SFB. Reconstructing past climate from noisy data. Science 2004, 306:679-682.

96. Franzke C, Lee S, Feldstein SB. Is the North Atlantic Oscillation a Breaking Wave? J Atmos Sci 2004, 61:145-160.

97. Woollings TJ, Hannachi A, Hoskins B, Turner BA. A regime view of the North Atlantic oscillation and its response to anthropogenic forcing. J Clim 2010, 23:1291-1307.

98. Buehler T, Raible CC, Stocker TF. On the relation of extreme North Atlantic blocking frequencies, cold spells, and droughts in ERA-40 in winter. Tellus $A$ 2011, 63:212-222. 